\title{
Direct Detection and Quantification of Bacterial Genes Associated with Inflammation in DNA Isolated from Stool
}

\author{
Ramón Gómez-Moreno'1,2, Iraida E. Robledo3 ${ }^{3}$, Abel Baerga-Ortiz ${ }^{1,2}$ \\ ${ }^{1}$ Department of Biochemistry, University of Puerto Rico, Medical Sciences Campus, San Juan, Puerto Rico \\ ${ }^{2}$ Molecular Sciences Building, University of Puerto Rico, Medical Sciences Campus, San Juan, Puerto Rico \\ ${ }^{3}$ Department of Microbiology and Medical Zoology, University of Puerto Rico, Medical Sciences Campus, \\ San Juan, Puerto Rico \\ Email: abel.baerga@upr.edu
}

Received 16 September 2014; revised 16 October 2014; accepted 10 November 2014

Copyright (C) 2014 by authors and Scientific Research Publishing Inc.

This work is licensed under the Creative Commons Attribution International License (CC BY).

http://creativecommons.org/licenses/by/4.0/

(c) (i) Open Access

\begin{abstract}
Although predominantly associated with health benefits, the gut microbiota has also been shown to harbor genes that promote inflammation. In this work, we report a method for the direct detection and quantification of these pro-inflammatory bacterial genes by PCR and qPCR in DNA extracted from human stool samples. PCR reactions were performed to detect (i) the pks island genes, (ii) $t c p C$, which is present in some strains of Escherichia coli and (iii) gelE presented in some strains of Enterococcus faecalis. Additionally, we screened for the presence of the following genes encoding cyclomodulins that disrupted mammalian cell division: (iv) cdt (which encodes the cytolethal distending toxin) and (v) cnf-1 (which encodes the cytotoxic necrotizing factor-1). Our results show that $20 \%$ of the samples $(\mathrm{N}=41)$ tested positive for detectable amounts of $p k s$ island genes, whereas $10 \%$ of individuals were positive for tcpC or gelE and only one individual was found to harbor the cnf-1 gene. Of the 13 individuals that were positive for at least one of the pro-inflammatory genes, 5 were found to harbor more than one. A quantitative version of the assay, which used real-time PCR, revealed the pro-inflammatory genes to be in high copy numbers: up to 1.3 million copies per $\mathrm{mg}$ of feces for the pks island genes. Direct detection of specific genes in stool could prove useful toward screening for the presence of pro-inflammatory bacterial genes in individuals with inflammatory bowel diseases or colorectal cancer.
\end{abstract}

\section{Keywords}

Microbiota, Stool Samples, Gut Inflammation, PCR, Microbial Biomarkers 


\section{Introduction}

The gut microbiota contains between 5 and 8 million active genes distributed over a great diversity of mostly uncultivable and novel species [1]-[3]. This complex community of bacteria has been shown to promote a healthy gut homeostasis as it is tasked with housekeeping functions like catabolism of complex polysaccharides, biosynthesis of vitamins and other essential nutrients, degradation of xenobiotics and the maintenance of serotonin levels in plasma [4]-[6]. Additionally, it is believed that a healthy commensal gut microbiota aids in the clearance of pathogenic bacteria and in the prevention of intestinal inflammation [7] [8]. Shifts in the composition of the resident microbiota, or microbial dysbioses, have been shown to lead to a variety of intestinal disorders [9] [10]. With the advent of powerful tools for parallel DNA sequencing, there has been a renewed interest in exploring the possible involvement of the gut microbiota in the development of intestinal disorders such as inflammatory bowel Disease (IBD), colorectal cancer (CRC) and gut-brain associated diseases [11]-[13].

Clinical correlations have been established that link chronic bacterial infections and intestinal disorders. For instance, the human pathogen Helicobacter pylori is widely recognized as a strong cofactor for the development of gastric adenocarcinoma [14]. Similarly, gut colonization with Clostridium difficile is followed by development of colitis, toxic megacolon and perforation [15].

In addition to the known gastrointestinal pathogens, there are the typically non-pathogenic members of the microbiota, which may harbor genes associated with inflammation. For instance, certain strains of commensal Escherichia coli have been found to harbor a genomic island encoding a colibactin polyketide synthase multienzyme ( $p k s$ island) that induces DNA damage followed by the activation of DNA repair pathways [16]. The presence of the pks island induces mammalian chromosome instability in mouse and human colon cells in culture [17]. Strains of $E$. coli harboring the $p k s$ island were found in higher frequency in mucosal samples from individuals suffering from CRC and IBD compared with the control group [18].

Other pro-inflammatory gene products found in certain strains of $E$. coli include $t c p C$, which has been found to impair toll-like receptor (TLR) function and the cytotoxic necrotizing factor-1 (CNF-1), an activator of oncogenic Rho GTPases [19]-[21]. Additionally, there are certain strains of commensal Enterococcus species that are not pathogenic but contain a subset of the virulence genes including gelE - a gene encoding a collagen-degrading metalloprotease which has been found to induce inflammation in a mouse model [22].

It has been established that these pro-inflammatory genes promote the colonization of pathogenic strains of bacteria. Substantially less clear is the effect of these pro-inflammatory genes when harbored by non-pathogenic commensal bacteria in the microbiota over a period of time [23]. Additionally, the distribution and frequency of most of these pro-inflammatory genes in the human population are not known and methods have not been implemented for the quick and direct detection of these genes in easily obtained stool samples.

In this work, we have developed a rapid assay for the detection of pro-inflammatory genes directly in a small stool sample $(0.5 \mathrm{~g})$. The assay can be performed in diagnostic format (classical PCR) or a quantitative format (rtPCR). Our results show that pro-inflammatory genes are highly prevalent (up to $20 \%$ of the samples tested) and in high enough copy number (up to 1.3 million copies per mg stool) for direct detection in a small stool sample. The assays described in this report could prove useful in future explorations of the relationship between the presence of these pro-inflammatory genes and intestinal diseases.

\section{Materials and Methods}

\subsection{Stool Samples}

Anonymous human stool samples were donated by a clinical laboratory (Laboratorio Clínico El Monte, San Juan, Puerto Rico, $\mathrm{N}=41$ ). Samples were stored at $-80^{\circ} \mathrm{C}$.

\subsection{DNA Extraction}

Bacterial DNA was extracted from 41 human stool samples using the QIAamp ${ }^{\circledR}$ DNA Stool Mini Kit (QIAGEN). Approximately $0.2 \mathrm{~g}$ stool was resuspended in $1.4 \mathrm{~mL}$ of ASL buffer. The bacterial DNA was extracted following the manufacturer's protocol and eluted in $200 \mu \mathrm{l}$ of the buffer included in the kit. A total of $5 \mu \mathrm{l}$ of DNA extract was used as template for the ensuing PCR reactions.

\subsection{Detection of Bacterial Genes by PCR}

A volume of $5 \mathrm{ul}$ of undiluted fecal DNA extract (from $0.2 \mathrm{mg}$ stool) was used and the PCR conditions are 
summarized in Table 1. All PCR reactions begin with an initial denaturation of 1 minute at $94^{\circ} \mathrm{C}$ followed by 30 cycles of denaturation ( 30 seconds at $94^{\circ} \mathrm{C}$ ), annealing (30 seconds at different temperatures shown in Table 1) and extension $\left(3\right.$ minutes at $\left.68^{\circ} \mathrm{C}\right)$. All reactions were finalized with a long extension step of 10 minutes at $72^{\circ} \mathrm{C}$ to ensure maximum detection. The detection of pks island genes was performed using the primer for the amplification of $c l b N$ genes that were described previously [23]. The detection of gelE was carried out using gelEspecific primers that were also described previously [24]. For the detection of $t c p C$ and $\operatorname{cnf}-1$, oligonucleotide primers were designed using the software Primer 3 (http://simgene.com/Primer3) on the nucelotide sequences for E. coli ECOR63 (GenBank: GQ903014.1) and E. coli MS 153-1 (NCBI: ZP_16446903.1). For the detection of $c d t$, primers were designed using the $c d t B$ subunit from Campylobacter jejuni subsp. jejuni 81-176 (GenBank: AAB06708.1).

\subsection{Purification of PCR Products}

The PCR products were separated on a 2\% agarose gel and extracted from the agarose gel using the QIAquick Gel Extraction Kit (QIAGEN).

\subsection{DNA Sequence Confirmation by the Sanger Method}

The DNA sequence for the amplified fragments was verified using the Sanger method for DNA sequencing at the RCMI Center for Genomics in Health Disparities and Rare Diseases at the University of Puerto Rico. The purified amplicon was sent for sequencing using the forward oligonucleotide primer for each of the products.

\subsection{Estimation of Gene Copy Number by Quantitative PCR (qPCR)}

In order to provide a quantitative estimate on the number of copies of each of the pro-inflammatory genes, we measured the PCR reaction in real time and compared the results for the DNA extracted from stool samples with known amounts of DNA extracted from isolated bacteria known to contain the genes. The qPCR reaction was performed with $6.8 \mu \mathrm{l}$ of stool DNA extract and the QuantiTect SYBR Green PCR kit (Qiagen) and was read on a Eppendorf Mastercycler Realplex.

\subsection{Calibration Curve}

A calibration curve was built for each gene by performing real-time PCR on the DNA extracts from a bacterial isolate known to contain at least a copy of the bacterial gene of interest. In order to identify strains that could serve as positive controls (or method calibrants) for the $p k s$ island, $t c p C$, and $c n f$ genes, we screened a collection of clinical isolates of $E$. coli that were part of a nosocomial infection surveillance study [25] and found several $E$. coli isolates that tested positive for one of the genes. The DNA extracted from these strains was used as positive

Table 1. Summary of PCR conditions for the detection of a panel of pro-inflammatory bacterial genes.

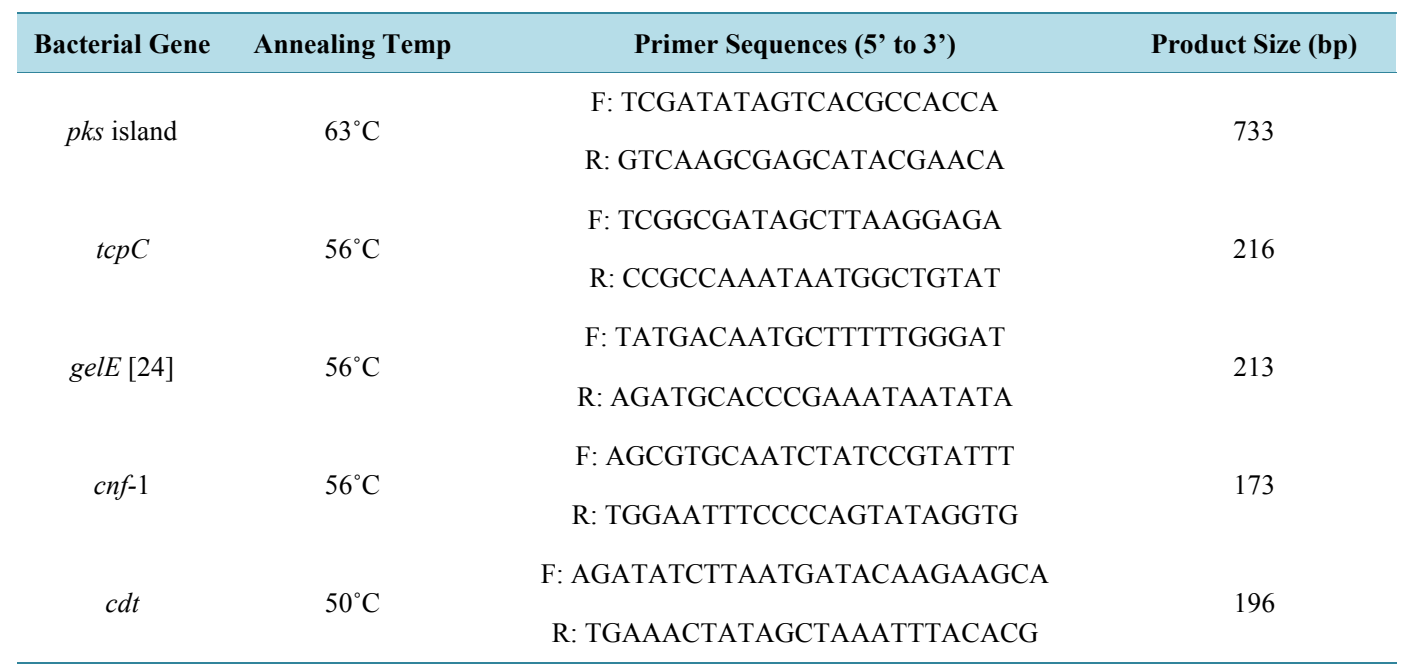


control in the PCR reaction, which was done in triplicate. The positive control for gelE was Enterococcus faecalis strain H32, an environmental isolate known to contain the gelE virulence gene and kindly donated by Dr. Luis Ríos-Hernández from University of Puerto Rico, Mayagüez Campus. The genome of E. coli contains 4.6 million base pairs and weighs $5.1 \times 10^{-15} \mathrm{~g}$. The genome of E. faecalis, somewhat smaller, weighs $3.6 \times 10^{-15} \mathrm{~g}$. Thus, the DNA copy number conversion can be determined from a measurement of absorbance at $260 \mathrm{~nm}$ according to the following relationship:

$$
\text { \#DNA copies } / \mu \mathrm{l}=\mathrm{A} 260 *\left(50 \times 10^{-9} \mathrm{~g} \mathrm{DNA} / \mu \mathrm{l}\right) /(\mathrm{GW})
$$

where A260 is the absorbance of the sample at $260 \mathrm{~nm}$ and $\mathrm{GW}$ is the weight in grams of the entire genome of the organism $\left(5.1 \times 10^{-15} \mathrm{~g}\right.$ for E. coli and $3.6 \times 10^{-15} \mathrm{~g}$ for E. faecalis $)$.

For example, the $p k s$ island gene standards were made with known amounts of E. coli DNA. Samples containing $384 \mathrm{ng} / \mu \mathrm{l}(75,294,120$ copies per $\mu \mathrm{l}), 100 \mathrm{ng} / \mu \mathrm{l}(19,607,843$ copies per $\mu \mathrm{l}), 10 \mathrm{ng} / \mu \mathrm{l}(1,960,784$ copies per $\mu \mathrm{l}), 1 \mathrm{ng} / \mu \mathrm{l}(196,078$ copies per $\mu \mathrm{l})$ and $0.1 \mathrm{ng} / \mu \mathrm{l}(19,607$ copies per $\mu \mathrm{l})$ were used as templates of the qPCR reaction monitored in real time.

The correlation coeffcient $\left(\chi^{2}\right)$ for each calibration curve was determined by the least squares method and the percentage efficiency of the PCR reaction calculated by implementing the equation:

$$
\text { Efficiency }=-1+10^{(-1 / \text { slope })}
$$

Typical positive values for the $p k s$ island range between $2800-1,300,000$ copies per $\mu$ l.

\section{Results}

\subsection{Detection and Prevalence of Pro-Inflammatory Genes in Stool Samples}

A total of 41 anonymous human stool samples were analyzed for the presence of the genes for $p k s$ island, $t c p C$, gelE, and $c n f-1$. The presence of bacteria was confirmed in all of the samples by amplification of the 16S-rRNA gene (data not shown). The presence of the $p k s$ island genes was established by the amplification of a DNA fragment of $733 \mathrm{bp}$ (Figure 1(a)). A total of 8 samples out of 41 were found to contain the gene for pks island (20\%). The other pro-inflammatory gene, $t c p C$, was detected in a total of 7 samples (17\%) as evidenced by the presence of a band of $216 \mathrm{bp}$ (Figure 1(b)) and the enterococcal gelE was found in 3 samples easily detected by a band of $213 \mathrm{bp}(7 \%)$. The gene for cytotoxic necrotizing factor-1 (cnf-1) was only found in a single sample while the gene for the cytolethal distending toxin $(c d t)$ was not found in this group of samples. The results from the PCR screens are summarized in Table 2.

A total of thirteen (13) samples were found to contain at least one of the four pro-inflammatory genes. Of these 13 samples, a total of eight (8) samples were found to contain only one of the genes and four samples were found to contain two pro-inflammatory genes. One result, corresponding to anonymous sample "Hu037" was found to contain three genes: $p k s$ island, $t c p C$ and gelE (Table 3). Future work will be aimed at establishing whether these individuals harboring multiple pro-inflammatory bacterial genes have a higher risk of developing intestinal disorders.

The DNA sequences for the PCR amplified pro-inflammatory bacterial genes were confirmed by performing Sanger sequencing on the gel-purified PCR products. By comparing the DNA sequences found in individual samples, we were able to make a preliminary assessment of the sequence variability for the pro-inflammatory bacterial genes. While the DNA sequences for the amplicons generated from $t c p C$ and gelE were exactly the same in all positive stool samples, the DNA sequence for the $p k s$ island amplicon showed variability around sequence positions 8312 and 8383 (numbering according to GeneBank accession No. AM229678). The amplicon generated from the $p k s$ island in samples $\mathrm{Hu} 033$, Hu037, Hu038 contains three distinct variants (Figure 2). Stool sample labeled $\mathrm{Hu} 033$ features A and $\mathrm{G}$ in positions 8312 and 8383, respectively. Meanwhile, the stool samples $\mathrm{Hu} 037$ and Hu038 have a G-A and A-A in those positions.

\subsection{Quantification of Pro-Inflammatory Genes in Stool}

From the PCR results visualized on an agarose gel, it was clear that some samples registered a more intense band than others, raising the possibility that some individuals harbor a higher content of bacterial pro-inflammatory genes than others. In order to provide a quantitative estimate of the number of copies of the pro-inflammatory genes per patient, we performed the PCR assay with real-time detection (Figure 3). A standard 

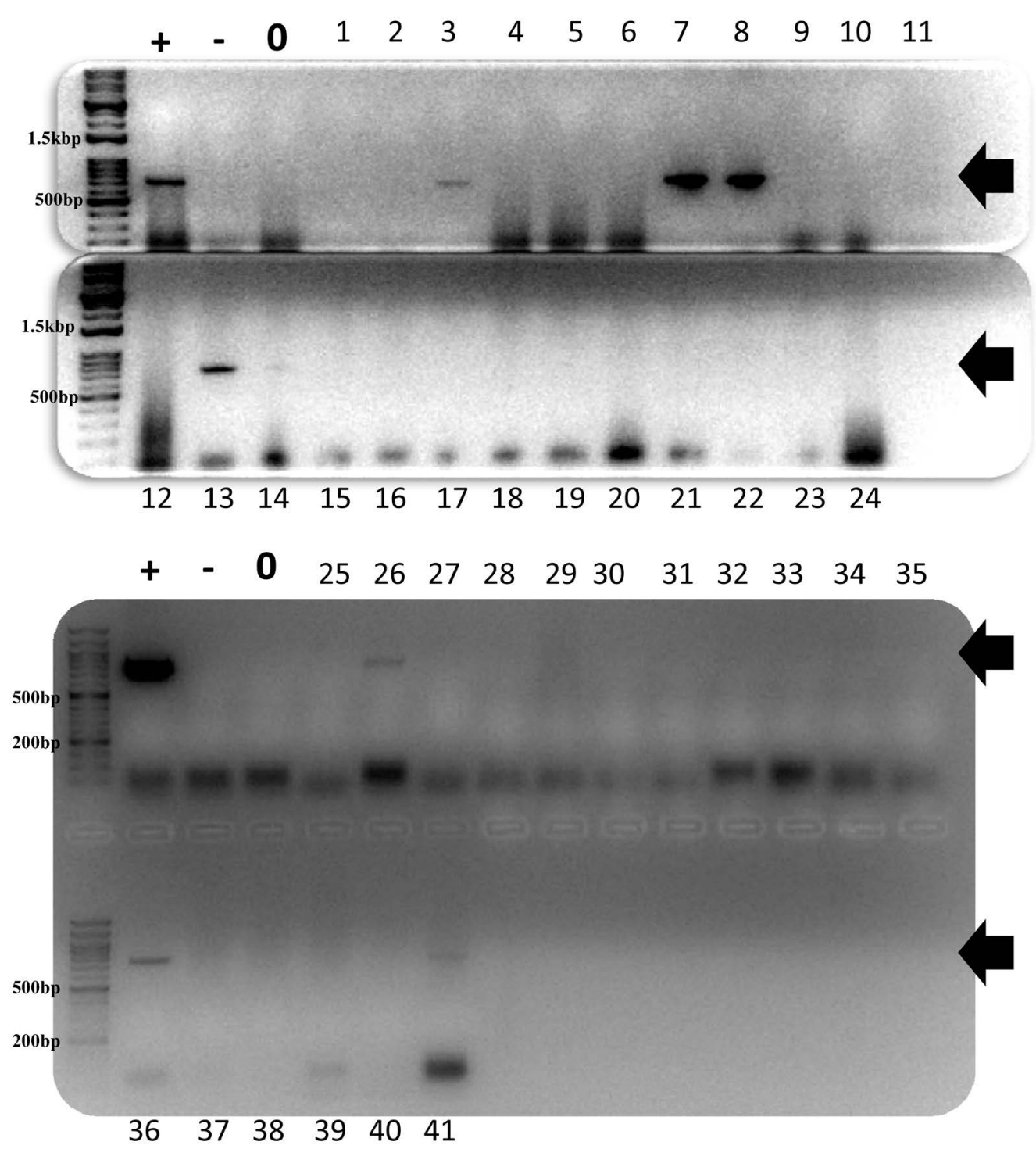

Figure 1. PCR amplification of the pks island genes was visualized on a $2 \%$ agarose gel in which the first four lanes contain the DNA size marker, a positive control $(+)$, a negative control $(-)$ and a blank $(0)$, respectively. The DNA size markers used for samples $1-24$ is $1 \mathrm{~kb}$ Opti-DNA Marker from ABM band for sample 25 - 41 the $100 \mathrm{bp}$ Opti-DNA Marker by ABM. The presence of the pks island gene can be established by the presence of a band at 733 bp (black arrows). The data for the 41 samples is shown in two different gels with eight positives $(3,7,8,13,14,26,36$ and 41$)$.

Table 2. Summary of the results from the PCR screening of pro-inflammatory bacterial genes from anonymous stool samples $(\mathrm{N}=41)$. A DNA calibration curve was made by real-time PCR measurements of samples with known DNA concentration and each point was measured in triplicate.

\begin{tabular}{cccccc}
\hline Bacterial Gene & \# Positives & $\%$ & $\begin{array}{c}\text { Calibration } \\
\text { Curve }\left(\chi^{2}\right)\end{array}$ & Efficiency (\%) & $\begin{array}{c}\text { Copy Number in } \\
\text { Positives per mg Stool }\end{array}$ \\
\hline$p k s$ island & 8 & 20 & 0.9991 & 114.092 & $2800-1,300,000$ \\
$t c p C$ & 7 & 17 & 0.9966 & 99.09 & $100,000-800,000$ \\
$g e l E$ & 3 & 7 & 0.9875 & 58.75 & $6000-260,000$ \\
$c n f-1$ & 1 & 2 & 0.9987 & 104.69 & 43,000 \\
$c d t$ & 0 & 0 & N/A & N/A & N/A \\
\hline
\end{tabular}




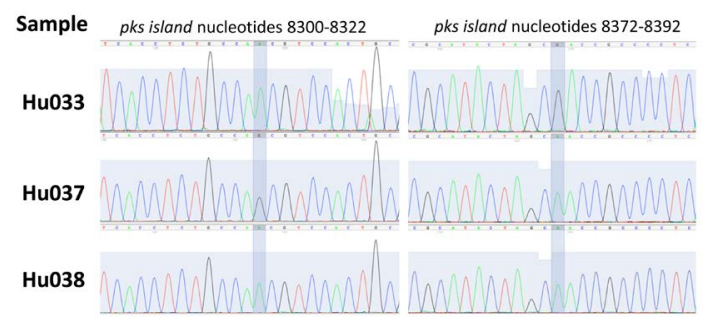

Figure 2. The DNA sequences for all the fragments generated in this study were confirmed by the Sanger method. Interestingly, three distinct variants of the $p k s$ island sequence were identified in three different samples (Hu033, Hu037 and Hu038). The sequencing chromatograms corresponding to regions 8300 - 8322 and 8372 - 8392 of the pks island gene sequence (GeneBank Accession No. AM229678) are shown for all three samples. Sequence variability was observed in positions 8312 and 8383 of this amplicon.

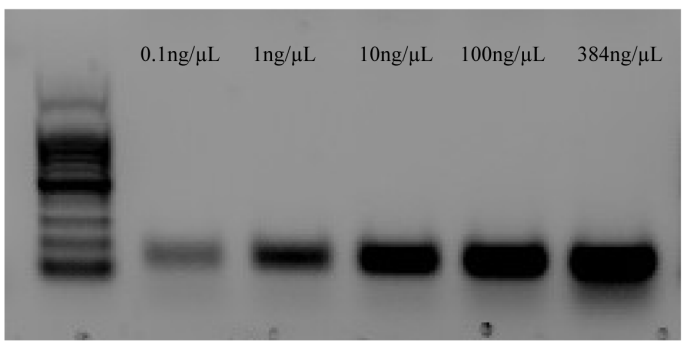

(a)

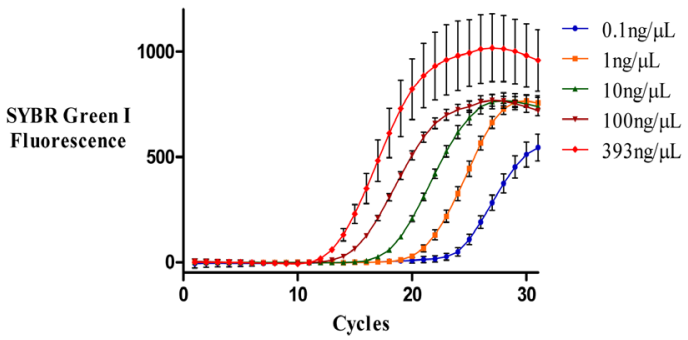

(b)

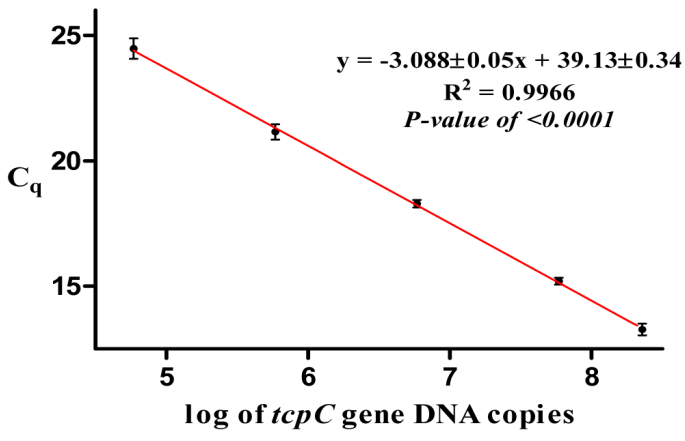

(c)

Figure 3. For the quantification of DNA copy number, a standard curve was generated for each of the pro-inflammatory genes as described in the methods section. Standards containing $393 \mathrm{ng} / \mu \mathrm{l}(77,058,825$ copies per $\mu \mathrm{l}), 100 \mathrm{ng} / \mu \mathrm{l}(19,607,843$ copies per $\mu \mathrm{l}), 10 \mathrm{ng} / \mu \mathrm{l}$ $(1,960,784$ copies per $\mu \mathrm{l}), 1 \mathrm{ng} / \mu \mathrm{l}(196,078$ copies per $\mu \mathrm{l})$ and $0.1 \mathrm{ng} / \mu \mathrm{l}(19,607$ copies per $\mu \mathrm{l})$ were used to make the calibration curve. Typical copy number estimates for $t c p C$-positive samples ranged from $100,000-800,000$ copies per $\mu$ l. In this figure we show (a) the agarose gel electrophoresis for the PCR amplification of tcpC gene using different known amounts of $E$. coli DNA in the reaction mixture, (b) the qPCR reaction for the standards monitored in real time and (c) the calibration curve for the quantification of $t c p C$ copies. 
Table 3. Stools samples positive for pro-inflammatory bacterial genes.

\begin{tabular}{cccccc}
\hline Samples & pks Island & tcpC & gelE & cnf-1 & cdt \\
HUO32 & + & - & - & - & - \\
HUO37 & + & + & + & - & - \\
HUO38 & + & - & - & - & - \\
HUO40 & - & + & - & - & - \\
HUO33 & + & + & - & - & - \\
HUO47 & + & - & - & - & - \\
PR014 & - & - & + & - & - \\
LEMB3_2 & + & + & - & - & - \\
LEMB3_6 & - & - & + & - & - \\
LEMB3_8 & - & + & - & - \\
LEMB3_12 & + & - & - & - \\
LEMB3_15 & - & + & - & - \\
LEMB3_17 & + & + & - & - \\
\hline
\end{tabular}

curve that was made with known amounts of DNA copies as described in the methods section, enabled the quantification of DNA copy number for each of the genes in the 41 stool samples. The number of copies of pks island among those who tested positive fluctuated between 2800 and 1.3 million copies per mg of stool analyzed and the number of gelE copies fluctuated between $6000-260,000$ copies per mg of stool. The amount of $t c p C$ DNA was less variable fluctuating between 100,000 - 800,000 copies per mg of stool. Future work will be aimed at establishing whether a correlation exists between a high copy number for these pro-inflammatory genes and a higher risk of developing gastrointestinal disorders.

\section{Discussion}

The elucidation of the role of the gut microbiota in human health is an active area of research [26]-[28]. A number of efforts worldwide have served to elucidate important associations between the microbiota and health [29]-[31]. For instance, an unequivocal link has been established between the gut microbiota and obesity [32] [33]. Additionally, the presence of pathogens such as Helicobacter pylori and Clostridium difficile has been found to correlate with inflammation and ultimately with the development of gastric cancer [14] [15]. More recently, there have been reports that the gram-negative bacterium of the genus Fusobacterium is more highly represented in colorectal tumor tissue than in normal mucosal tissue from the same patients [34] [35].

In this report, instead of focusing on the presence of bacterial species, we have developed a quantitative assay to detect specific bacterial genes that have been associated with inflammation, directly in a small stool sample. Some of these genes in this report were found to be present in as many as $20 \%$ of the stool samples and in copy numbers as high as 1.3 million copies per $\mathrm{mg}$ of stool. The assay described in this report provides a quick method for the screening of stool samples to ascertain the presence of pro-inflammatory genes in case-control studies involving individuals with colorectal cancer or inflammatory bowel diseases. The genes in this report, namely $p k s$ island, $t c p C$, cnf-1, gelE and $c d t$, have all been the subject of scrutiny for their possible crosstalk with inflammatory processes. Here we discuss each of them separately:

pks Island Of the genes tested, the pks island was the most prevalent and was found in high copy numbers $\left(>10^{6}\right.$ copies per $\mathrm{mg}$ stool). The $p k s$ genomic island encodes a number of multidomain enzymes termed polyketide synthases that typically synthesize secondary metabolites in numerous microbial species, although the actual compound made by this multienzyme has not been chemically characterized [16]. The pks island has been found in pathogenic and in non-pathogenic strains of E. coli [23]. Although the pks island is not pro-inflammatory per se, the presence of this genomic island in some strains of $E$. coli has been implicated in the formation of 
colorectal tumors in inflammation-prone mice, which lack the inteleukin-10 gene [18]. That study also reported that the $p k s$ island was more highly represented in the intestinal mucosa from colorectal cancer (CRC) patients than in non-CRC controls [18]. In the present study, the $p k s$ island genes were found in $20 \%$ of the stool samples analyzed, a frequency consistent with previous findings reporting the $p k s$ island to be present in $20 \%$ of strains isolated from human mucosa samples from non-cancer donors [18] and in $32 \%$ of E. coli strains isolated from the feces of hospitalized veterans [23]. Although our assay is carried out on total DNA isolated from a stool sample, without strain isolation or cultivation, our results are similar to those obtained using the more conventional culture-dependent method.

$t c p C$ Similarly, the $t c p C$ gene has been found in strains of $E$. coli associated with severe kidney infection [36]. $t c p C$ subverts toll-like receptor-dependent inflammation by binding directly to the receptor, resulting in the formation of kidney abscesses in mice infected with strains of uropathogenic E. coli [19]. However, there are no reports of the $t c p C$ gene in the commensal $E$. coli strains that inhabit the GI tract. Much to our surprise, seven (7) of our fecal samples were found to harbor the tcpC gene in high enough copy number to detect by PCR.

cnf-1 The cnf-1 gene encodes an enzyme, the cytotoxic necrotizing factor-1, which is found in strains of $E$. coli commonly associated with urinary tract infections [37]. The Cnf enzyme deaminates Rho GTPase in glutamine 63 causing it to be locked in the active GTP-bound state. Although the cnf-1 gene has been found in bacterial isolates from feces of children with diarrhea, this is the first report of this gene in high enough copies to be detected directly in stool [38]. Only one (1) sample in the present study was found to contain the $c n f-1$ gene.

gelE GelE gene encodes a metallo-collagenase from the genus Enterococcus. The GelE collagenase has been found to promote chronic inflammation in mice lacking the interleukin-10 gene [22]. More recently, gelE gene was found in higher frequency in bacterial isolates from the feces of children with IBD vs. children without IBD [39]. Here we report 3 stool samples with detectable levels of gelE gene directly in stool.

With the growth of affordable parallel sequencing methods, scientists have gained a whole new view of the diversity of bacterial species (or taxa) in a complex community such as the gut microbiota [40] [41]. One important line of experimentation centers on building a comprehensive list of bacterial species present in the community for comparison between disease cases and controls. However, most community profiling efforts rely on molecular markers (such as the 16S rRNA gene) and do not necessarily detect additional genes that may have been acquired in time. For instance, the bacterial community profile for any stool sample would likely reveal the presence of $E$. coli, but it would not necessarily show whether the E. coli strains in the sample contain pro-inflammatory genes ( $t c p C$, pks island, etc.). In addition, $E$. coli is not the only species that harbor the $p k s$ island, as the genes can also be carried by other bacteria, such as Klebsiella pneumoniae, Enterobacter aerogenes and Citrobacter koseri [42].

The assay described in this report is meant to complement ongoing efforts, whether by bacterial community profiling or by shotgun metagenomics, to ascertain the presence of harmful or protective genes, in fecal samples regardless of which species carries the genes. Clearly, other complementary assays will have to be developed to determine whether the pro-inflammatory bacterial genes are being transcribed in the gut, or whether the gene products are being synthesized in active form. But the development of a quick and quantitative assay for the detection of pro-inflammatory genes in stool samples is a first step toward the quick interrogation of stool samples in large-scale case-control studies involving IBD and CRC patients.

\section{Conclusion}

We report the detection, directly in DNA extracted from a fecal sample, of several genes of bacterial origin which had been previously associated with inflammation. Although the presence of these genes had been ascertained in strains of bacteria known to colonize other tissues, this is the first report of these genes being found in the normal commensal flora. The assay described in this report provides a quick and inexpensive method for the analysis of a large number of samples from case-control studies involving patients of IBD or CRC.

\section{Acknowledgements}

This publication was made possible by NSF grant CHE0953254 to AB-O and NIGMS grant R25GM061838 to RG-M. The laboratory also received support from an institutional grant to the Puerto Rico Clinical and Translational Consortium (PRCTRC: U54MD007587). Shared instrumentation was purchased with NIH Grant G12RR03051 (RCMI Program). 
The authors also wish to thank Rosa I. Martínez, MT from Laboratorio Clínico El Monte in San Juan, Puerto Rico for the kind donation of stool sample remnants used in this study, and Dr. Luis Ríos-Hernández from the University of Puerto Rico in Mayagüez for providing the E. faecalis strains used as positive controls. The authors express gratitude to Carmelo Orengo, Vilmarie Mercado and Caleb Fernández for their technical support.

\section{References}

[1] Balter, M. (2012) Taking Stock of the Human Microbiome and Disease. Science, 336, 1246-1247. http://dx.doi.org/10.1126/science.336.6086.1246

[2] Eckburg, P.B., Bik, E.M., Bernstein, C.N., Purdom, E., Dethlefsen, L., Sargent, M., Gill, S.R., Nelson, K.E. and Relman, D.A. (2005) Diversity of the Human Intestinal Microbial Flora. Science, 308, 1635-1638. http://dx.doi.org/10.1126/science.1110591

[3] Blaser, M., Bork, P., Fraser, C., Knight, R. and Wang, J. (2013) The Microbiome Explored: Recent Insights and Future Challenges. Nature Reviews Microbiology, 11, 213-217. http://dx.doi.org/10.1038/nrmicro2973

[4] Qin, J., Li, R., Raes, J., Arumugam, M., Burgdorf, K.S., Manichanh, C., Nielsen, T., Pons, N., Levenez, F., Yamada, T., Mende, D.R., Li, J., Xu, J., Li, S., Li, D., Cao, J., Wang, B., Liang, H., Zheng, H., Xie, Y., Tap, J., Lepage, P., Bertalan, M., Batto, J., Hansen, T., Le Paslier, D., Linneberg, A., Nielsen, H., Bjorn, Pelletier, E., Renault, P., Sicheritz-Ponten, T., Turner, K., Zhu, H., Yu, C., Li, S., Jian, M., Zhou, Y., Li, Y., Zhang, X., Li, S., Qin, N., Yang, H., Wang, J., Brunak, S., Dore, J., Guarner, F., Kristiansen, K., Pedersen, O., Parkhill, J., Weissenbach, J., Bork, P., Dusko Ehrlich, S. and Wang, J. (2010) A Human Gut Microbial Gene Catalogue Established by Metagenomic Sequencing. Nature, 464, 59-65. http://dx.doi.org/10.1038/nature08821

[5] Wikoff, W.R., Anfora, A.T., Liu, J., Schultz, P.G., Lesley, S.A., Peters, E.C. and Siuzdak, G. (2009) Metabolomics Analysis Reveals Large Effects of Gut Microflora on Mammalian Blood Metabolites. Proceedings of the National Academy of Sciences of the United States of America, 106, 3698-3703. http://dx.doi.org/10.1073/pnas.0812874106

[6] Ursell, L.K. and Knight, R. (2013) Xenobiotics and the Human Gut Microbiome: Metatranscriptomics Reveal the Active Players. Cell Metabolism, 17, 317-318. http://dx.doi.org/10.1016/j.cmet.2013.02.013

[7] Sperandio, V. (2012) Microbiology. Virulence or competition? Science, 336, 1238-1239. http://dx.doi.org/10.1126/science.1223303

[8] Mazmanian, S.K., Round, J.L. and Kasper, D.L. (2008) A Microbial Symbiosis Factor Prevents Intestinal Inflammatory Disease. Nature, 453, 620-625. http://dx.doi.org/10.1038/nature07008

[9] DuPont, A.W. and DuPont, H.L. (2011) The Intestinal Microbiota and Chronic Disorders of the Gut. Nature Reviews Gastroenterology and Hepatology, 8, 523-531. http://dx.doi.org/10.1038/nrgastro.2011.133

[10] Manichanh, C., Borruel, N., Casellas, F. and Guarner, F. (2012) The Gut Microbiota in IBD. Nature Reviews Gastroenterology and Hepatology, 9, 599-608.

[11] Frank, D.N., St Amand, A.L., Feldman, R.A., Boedeker, E.C., Harpaz, N. and Pace, N.R. (2007) Molecular-Phylogenetic Characterization of Microbial Community Imbalances in Human Inflammatory Bowel Diseases. Proceedings of the National Academy of Sciences of the United States of America, 104, 13780-13785. http://dx.doi.org/10.1073/pnas.0706625104

[12] Sears, C.L. and Garrett, W.S. (2014) Microbes, Microbiota, and Colon Cancer. Cell Host \& Microbe, 15, 317-328. http://dx.doi.org/10.1016/j.chom.2014.02.007

[13] Kinross, J.M., Darzi, A.W. and Nicholson, J.K. (2011) Gut Microbiome-Host Interactions in Health and Disease. Genome Medicine, 3, 14. http://dx.doi.org/10.1186/gm228

[14] Parsonnet, J., Friedman, G.D., Vandersteen, D.P., Chang, Y., Vogelman, J.H., Orentreich, N. and Sibley, R.K. (1991) Helicobacter pylori Infection and the Risk of Gastric Carcinoma. New England Journal of Medicine, 325, 1127-1131. http://dx.doi.org/10.1056/NEJM199110173251603

[15] Trudel, J.L. (2007) Clostridium difficile Colitis. Clinics in Colon and Rectal Surgery, 20, 13-17. http://dx.doi.org/10.1055/s-2007-970195

[16] Nougayrède, J., Homburg, S., Taieb, F., Boury, M., Brzuszkiewicz, E., Gottschalk, G., Buchrieser, C., Hacker, J., Dobrindt, U. and Oswald, E. (2006) Escherichia coli Induces DNA Double-Strand Breaks in Eukaryotic Cells. Science, 313, 848-851. http://dx.doi.org/10.1126/science.1127059

[17] Cuevas-Ramos, G., Petit, C.R., Marcq, I., Boury, M., Oswald, E. and Nougayrède, J. (2010) Escherichia coli Induces DNA Damage in Vivo and Triggers Genomic Instability in Mammalian Cells. Proceedings of the National Academy of Sciences of the United States of America, 107, 11537-11542. http://dx.doi.org/10.1073/pnas.1001261107

[18] Arthur, J.C., Perez-Chanona, E., Mühlbauer, M., Tomkovich, S., Uronis, J.M., Fan, T., Campbell, B.J., Abujamel, T., Dogan, B., Rogers, A.B., Rhodes, J.M., Stintzi, A., Simpson, K.W., Hansen, J.J., Keku, T.O., Fodor, A.A. and Jobin, C. 
(2012) Intestinal Inflammation Targets Cancer-Inducing Activity of the Microbiota. Science, 338, 120-123. http://dx.doi.org/10.1126/science.1224820

[19] Yadav, M., Zhang, J., Fischer, H., Huang, W., Lutay, N., Cirl, C., Lum, J., Miethke, T. and Svanborg, C. (2010) Inhibition of TIR Domain Signaling by TcpC: MyD88-Dependent and Independent Effects on Escherichia coli Virulence. PLoS Pathogens, 6, e1001120. http://dx.doi.org/10.1371/journal.ppat.1001120

[20] Fabbri, A., Travaglione, S., Ballan, G., Loizzo, S. and Fiorentini, C. (2013) The Cytotoxic Necrotizing Factor 1 from $E$. coli: A Janus Toxin Playing with Cancer Regulators. Toxins (Basel), 5, 1462-1474. http://dx.doi.org/10.3390/toxins5081462

[21] Garcia, T.A., Ventura, C.L., Smith, M.A., Merrell, D.S. and O’Brien, A.D. (2013) Cytotoxic Necrotizing Factor 1 and Hemolysin from Uropathogenic Escherichia coli Elicit Different Host Responses in the Murine Bladder. Infection and Immunity, 81, 99-109. http://dx.doi.org/10.1128/IAI.00605-12

[22] Steck, N., Hoffmann, M., Sava, I.G., Kim, S.C., Hahne, H., Tonkonogy, S.L., Mair, K., Krueger, D., Pruteanu, M., Shanahan, F., Vogelmann, R., Schemann, M., Kuster, B., Sartor, R.B. and Haller, D. (2011) Enterococcus faecalis Metalloprotease Compromises Epithelial Barrier and Contributes to Intestinal Inflammation. Gastroenterology, 141, 959-971. http://dx.doi.org/10.1053/j.gastro.2011.05.035

[23] Johnson, J.R., Johnston, B., Kuskowski, M.A., Nougayrede, J. and Oswald, E. (2008) Molecular Epidemiology and Phylogenetic Distribution of the Escherichia coli pks Genomic Island. Journal of Clinical Microbiology, 46, 39063911. http://dx.doi.org/10.1128/JCM.00949-08

[24] Vankerckhoven, V., Van Autgaerden, T., Vael, C., Lammens, C., Chapelle, S., Rossi, R., Jabes, D. and Goossens, H. (2004) Development of a Multiplex PCR for the Detection of asa1, gelE, cylA, esp, and Hyl Genes in Enterococci and Survey for Virulence Determinants among European Hospital Isolates of Enterococcus faecium. Journal of Clinical Microbiology, 42, 4473-4479. http://dx.doi.org/10.1128/JCM.42.10.4473-4479.2004

[25] Robledo, I.E., Aquino, E.E. and Vazquez, G.J. (2011) Detection of the KPC Gene in Escherichia coli, Klebsiella pneumoniae, Pseudomonas aeruginosa, and Acinetobacter baumannii during a PCR-Based Nosocomial Surveillance Study in Puerto Rico. Antimicrobial Agents and Chemotherapy, 55, 2968-2970. http://dx.doi.org/10.1128/AAC.01633-10

[26] Hood, L. (2012) Tackling the Microbiome. Science, 336, 1209. http://dx.doi.org/10.1126/science.1225475

[27] Zaneveld, J., Turnbaugh, P.J., Lozupone, C., Ley, R.E., Hamady, M., Gordon, J.I. and Knight, R. (2008) Host-Bacterial Coevolution and the Search for New Drug Targets. Current Opinion in Chemical Biology, 12, 109-114. http://dx.doi.org/10.1016/j.cbpa.2008.01.015

[28] Kuczynski, J., Costello, E.K., Nemergut, D.R., Zaneveld, J., Lauber, C.L., Knights, D., Koren, O., Fierer, N., Kelley, S.T., Ley, R.E., Gordon, J.I. and Knight, R. (2010) Direct Sequencing of the Human Microbiome Readily Reveals Community Differences. Genome Biology, 11, 210.

[29] De Palma, G., Collins, S.M., Bercik, P. and Verdu, E.F. (2014) The Microbiota-Gut-Brain Axis in Gastrointestinal Disorders: Stressed Bugs, Stressed Brain or Both? Journal of Physiology, 592, 2989-2997. http://dx.doi.org/10.1113/jphysiol.2014.273995

[30] Belkaid, Y. and Hand, T.W. (2014) Role of the Microbiota in Immunity and Inflammation. Cell, 157, 121-141. http://dx.doi.org/10.1016/j.cell.2014.03.011

[31] Haiser, H.J. and Turnbaugh, P.J. (2012) Is It Time for a Metagenomic Basis of Therapeutics? Science, 336, $1253-1255$. http://dx.doi.org/10.1126/science.1224396

[32] Bäckhed, F., Ding, H., Wang, T., Hooper, L.V., Koh, G.Y., Nagy, A., Semenkovich, C.F. and Gordon, J.I. (2004) The Gut Microbiota as an Environmental Factor that Regulates Fat Storage. Proceedings of the National Academy of Sciences of the United States of America, 101, 15718-15723. http://dx.doi.org/10.1073/pnas.0407076101

[33] Turnbaugh, P.J., Ley, R.E., Mahowald, M.A., Magrini, V., Mardis, E.R. and Gordon, J.I. (2006) An Obesity-Associated Gut Microbiome with Increased Capacity for Energy Harvest. Nature, 444, 1027-1031. http://dx.doi.org/10.1038/nature05414

[34] McCoy, A.N., Araujo-Perez, F., Azcarate-Peril, A., Yeh, J.J., Sandler, R.S. and Keku, T.O. (2013) Fusobacterium Is Associated with Colorectal Adenomas. PLoS ONE, 8, e53653. http://dx.doi.org/10.1371/journal.pone.0053653

[35] Keku, T.O., McCoy, A.N. and Azcarate-Peril, A.M. (2013) Fusobacterium spp. and Colorectal Cancer: Cause or Consequence? Trends in Microbiology, 21, 506-508. http://dx.doi.org/10.1016/j.tim.2013.08.004

[36] Cirl, C., Wieser, A., Yadav, M., Duerr, S., Schubert, S., Fischer, H., Stappert, D., Wantia, N., Rodriguez, N., Wagner, H., Svanborg, C. and Miethke, T. (2008) Subversion of Toll-Like Receptor Signaling by a Unique Family of Bacterial Toll/Interleukin-1 Receptor Domain-Containing Proteins. Nature Medicine, 14, 399-406. http://dx.doi.org/10.1038/nm1734

[37] Travaglione, S., Loizzo, S., Ballan, G., Fiorentini, C. and Fabbri, A. (2014) The E. coli CNF1 as a Pioneering Therapy 
for the Central Nervous System Diseases. Toxins (Basel), 6, 270-282. http://dx.doi.org/10.3390/toxins6010270

[38] Elliott, S.J., Srinivas, S., Albert, M.J., Alam, K., Robins-Browne, R.M., Gunzburg, S.T., Mee, B.J. and Chang, B.J. (1998) Characterization of the Roles of Hemolysin and Other Toxins in Enteropathy Caused by Alpha-Hemolytic Escherichia coli Linked to Human Diarrhea. Infection and Immunity, 66, 2040-2051.

[39] Golinska, E., Tomusiak, A., Gosiewski, T., Wiecek, G., Machul, A., Mikolajczyk, D., Bulanda, M., Heczko, P.B. and Strus, M. (2013) Virulence Factors of Enterococcus Strains Isolated from Patients with Inflammatory Bowel Disease. World Journal of Gastroenterology, 19, 3562-3572. http://dx.doi.org/10.3748/wjg.v19.i23.3562

[40] Caporaso, J.G., Lauber, C.L., Walters, W.A., Berg-Lyons, D., Huntley, J., Fierer, N., Owens, S.M., Betley, J., Fraser, L., Bauer, M., Gormley, N., Gilbert, J.A., Smith, G. and Knight, R. (2012) Ultra-High-Throughput Microbial Community Analysis on the Illumina HiSeq and MiSeq Platforms. ISME Journal, 6, 1621-1624. http://dx.doi.org/10.1038/ismej.2012.8

[41] Navas-Molina, J.A., Peralta-Sanchez, J.M., Gonzalez, A., McMurdie, P.J., Vazquez-Baeza, Y., Xu, Z., Ursell, L.K., Lauber, C., Zhou, H., Song, S.J., Huntley, J., Ackermann, G.L., Berg-Lyons, D., Holmes, S., Caporaso, J.G. and Knight, R. (2013) Advancing Our Understanding of the Human Microbiome Using QIIME. Methods in Enzymology, 531, 371-444. http://dx.doi.org/10.1016/B978-0-12-407863-5.00019-8

[42] Putze, J., Hennequin, C., Nougayrede, J., Zhang, W., Homburg, S., Karch, H., Bringer, M., Fayolle, C., Carniel, E., Rabsch, W., Oelschlaeger, T.A., Oswald, E., Forestier, C., Hacker, J. and Dobrindt, U. (2009) Genetic Structure and Distribution of the Colibactin Genomic Island among Members of the Family Enterobacteriaceae. Infection and Immunity, 77, 4696-4703. http://dx.doi.org/10.1128/IAI.00522-09 
Scientific Research Publishing (SCIRP) is one of the largest Open Access journal publishers. It is currently publishing more than 200 open access, online, peer-reviewed journals covering a wide range of academic disciplines. SCIRP serves the worldwide academic communities and contributes to the progress and application of science with its publication.

Other selected journals from SCIRP are listed as below. Submit your manuscript to us via either submit@scirp.org or Online Submission Portal.
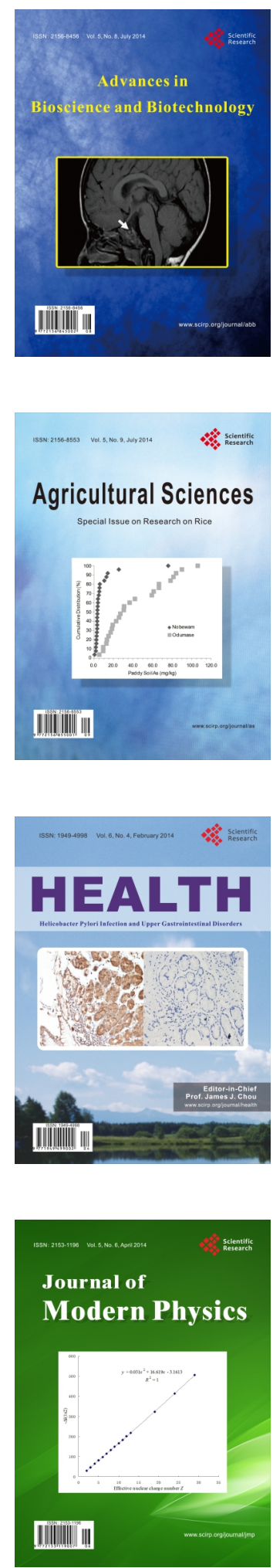
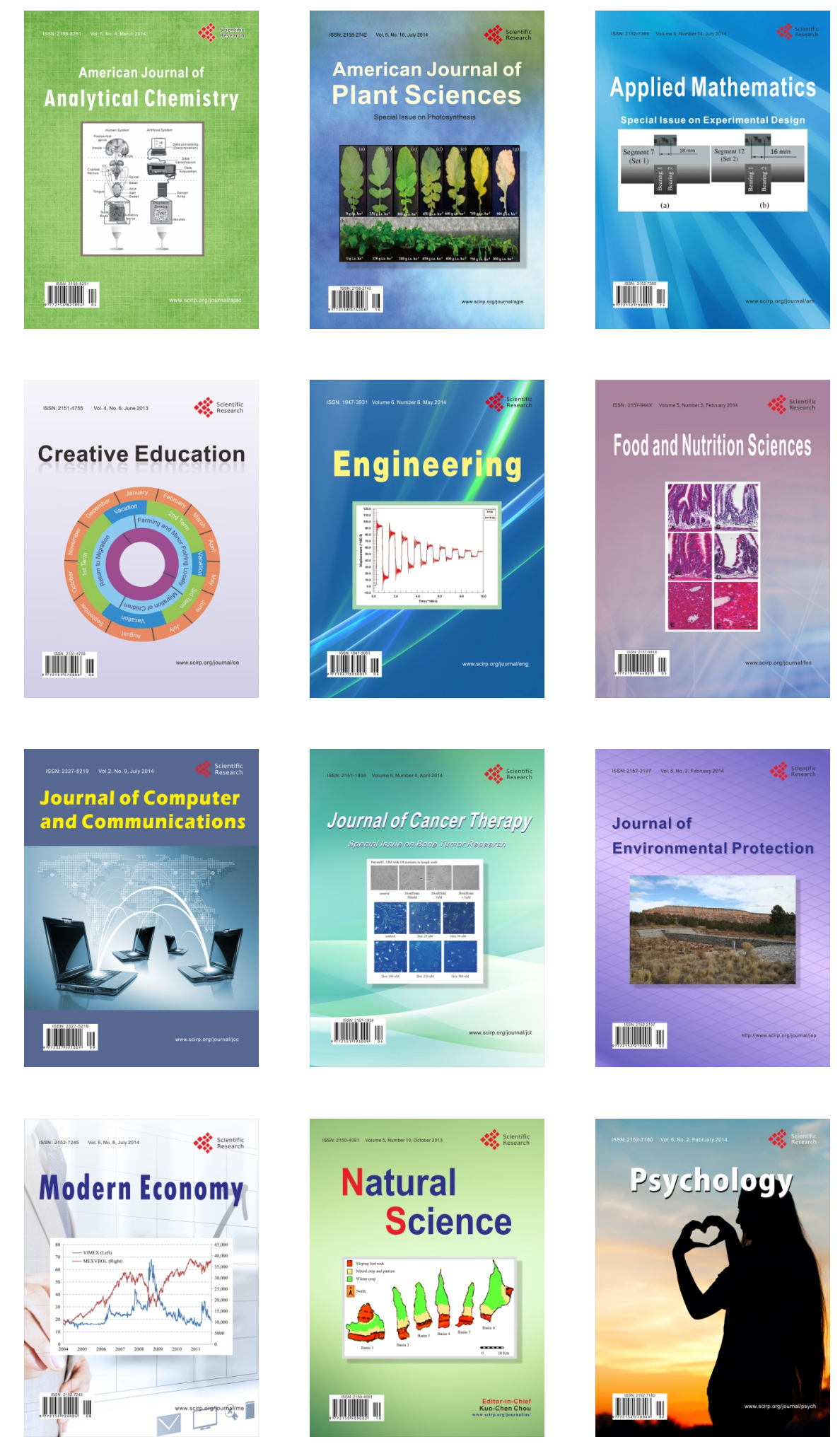